\title{
Reverse Phase HPLC Profiling of Antioxidant and Antimicrobial Activities of Sarcochlamys pulcherrima (Roxb.) Gaud.
}

\author{
Pradip Doley ${ }^{1}$, Naorem Manglembi Devi ${ }^{2},{ }^{*}$ Ch. B. Singh ${ }^{2}$, A.V. Singh ${ }^{1}$ \\ ${ }^{1}$ Department of Botany, Rajiv Gandhi University, Rono Hills, Itanagar 79111, Arunachal Pradesh, India \\ 2Institute of Bioresource and Sustainable Development, Department of Biotechnology, Imphal 795001, Manipur, India
}

\begin{abstract}
The total phenolics content, total flavonoids content, antioxidant activity and antimicrobial activity of methanol extract and its derived fractions from Sarcochlamys pulcherrima (Roxb.) Gaud. were evaluated. The plant material was initially extracted with methanol. The fractionation was carried out using liquid-liquid extraction with hexane, ethyl acetate, n-butanol, and water. The Folin-Ciocalteu assay was used to quantify total phenolics content, Aluminum Chloride assay to quantify total flavonoids content, DPPH (2, 2-diphenyl-1-picrylhydrazine) and reducing power assay are to determine antioxidant activity. The ethyl acetate fraction was observed to contain high phenolic content $(201.37 \mathrm{mg} / \mathrm{g}$ ) followed by n-butanol fraction (197.76 mg/g), methanol extract $(136.93 \mathrm{mg})$, water fraction $(55.05 \mathrm{mg} / \mathrm{g})$ and hexane fraction $(36.94 \mathrm{mg} / \mathrm{g})$ respectively. The flavonoids content ranges from 109.48 $\mathrm{mg} / \mathrm{g}$ to $8.63 \mathrm{mg} / \mathrm{g}$ dry extract. The highest antioxidant activity was found in n-butanol fraction $(\mathrm{EC} 50=14.69 \mu \mathrm{g} / \mathrm{mL}$ in $\mathrm{DPPH}$ and $162.65 \mu \mathrm{g} / \mathrm{mL}$ in reducing power). The antimicrobial activity of the samples was evaluated based on inhibition zone using agar-well diffusion assay and minimal inhibition concentration (MIC) values. Hexane fraction had no antimicrobial effect against test microorganisms. The zone of inhibitions ranged from $11 \mathrm{~mm}$ to $6 \mathrm{~mm}$. The n-butanol fraction possessed the highest antimicrobial activity against E. coli among the four fractions with MIC value of $0.781 \mathrm{mg} / \mathrm{mL}$. In addition rutin, gallic acid, quercetin and kaempferol were quantified by reverse phase high performance liquid chromatography (HPLC) method. In ethyl acetate and $\mathrm{n}$ butanol fraction, observed large amount rutin $(77.53 \pm 7.57 \mathrm{mg} / \mathrm{g} ; 77.45 \pm 1.71 \mathrm{mg} / \mathrm{g})$ and gallic acid $(61.01 \pm 2.34 \mathrm{mg} / \mathrm{g} ; 22.75 \pm 1.54$ $\mathrm{mg} / \mathrm{g}$ ) as compared to the quercetin and kaempferol.
\end{abstract}

Key Words: Sarcochlamys pulcherrima, Total phenol, Total flavonoid, Antioxidant, Antimicrobial, HPLC.

\section{INTRODUCTION}

Plant has been used as source of medicine for the treatment of various ailments since time immemorial (Maqsood et al., 2010). Medicinal plants are the excellent source of natural products and phytochemicals which possess many properties like antioxidant, anticancer, antiinflammatory and antimicrobial. Natural antioxidants can defend the human body from free radicals. A free radicle is defined as any atom or molecule that contains one or more unpaired electrons. Reactive oxygen species (ROS) is composed of both oxygen radicals, such as superoxide anion $\left(\mathrm{O}_{2}^{-}\right)$, hydroxyl $\left(\mathrm{OH}^{-}\right)$, peroxyl $\left(\mathrm{RO}_{2}^{-}\right)$, and hydroperoxyl $\left(\mathrm{HO}_{2}^{-}\right)$radicals, and certain nonradical oxidizing agents, such as hydrogen peroxide $\left(\mathrm{H}_{2} \mathrm{O}_{2}\right)$, hypochlorous acid $(\mathrm{HOCl})$, and ozone $\left(\mathrm{O}_{3}\right)$, that can be converted easily to into radicals (Bayr, 2005). Free radical, which are normally produced in numerous biochemical reactions in the body lead to oxidative stress thereby causing damage to cell membranes, lipids, proteins and nucleic acids (Droge, 2002); have been implicated as mediators of many human diseases such as cancer (Muramatsu, et al., 1995), atherosclerosis (Das et al., 1997), inflammation and heart diseases (Sorbara and Girardin, 2011). Antioxidants are agents which scavenge the free radical or prevent the oxidation of easily oxidable substrates (Pisoschi and Danet, 2009). Among the various natural antioxidants, polyphenols are reported to be active with redox properties, which allow them to act as reducing agents,

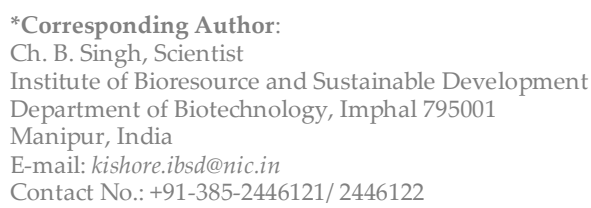

hydrogen donators, and singlet oxygen quenchers (Kahkonen et al., 1999; Proestos et al., 2006).

The North-East India, due to its climatic conditions and flora diversity, is located in the Eastern-Himalayan regions with a high diversity of ethnomedicinal plant, some of them with great gastronomic relevance. Within the local edible species, Sarcochlamys pulcherrima is one the most important plant because of its high consumption by the Mising tribe of Assam, India. Sarcochlamys pulcherrima (Roxb.) Gaud. is a single species known to the genus Sarcochlamys belongs to the family Urticaceae ( $\mathrm{Wu}$ et al., 2013) and it is commonly known as Ombey in Mising community. Sarcochlamys pulcherrima has been used as folk medicine for the treatment of diarrhea and dysentery (Sharma and Pegu, 2011). Young shoots and leaves are eaten as vegetables especially by the Mising tribe of Assam with pork based on the belief that it kills the tap worms and facilitate the digestion of fats.

In this experiment our aim is focused on estimation of some phenolic compound according to their bioactivity. Many authors have reported that $S$. pulcherrrima is shown to have high amount of phenolic compound. However the composition of phenolic compound is remains unclear and here we have shown estimation of some known standard antioxidants using reverse phase HPLC. In our assay plant extract have shown high antioxidant and antimicrobial activity which is being reported to validate the traditional use of S. pulcherrima as a crude drug as well as food.

\section{MATERIALS AND METHODS}

\section{Chemicals}

Folin-Ciocalteu phenol reagent were purchased from Merck and 2, 2-diphenyl-1-picrylhydrazyl (DPPH), sodium carbonate $\left(\mathrm{Na}_{2} \mathrm{CO}_{3}\right)$, sodium hydroxide $(\mathrm{NaOH})$, 
disodium hydrogen phosphate $\left(\mathrm{Na}_{2} \mathrm{HPO}_{4}\right)$, sodium dihydrogen phosphate $\left(\mathrm{NaH}_{2} \mathrm{PO}_{4}\right)$, aluminum chloride, potassium ferricyanide $\left[\mathrm{K}_{3} \mathrm{Fe}(\mathrm{CN})_{6}\right]$, trichloroacetic acid (TCA), ferric chloride $\left(\mathrm{FeCl}_{3}\right)$, and rutin were procured from HiMedia Laboratories Pvt. Ltd, Mumbai, India. Gallic acid, catechin, quercetin, kaempferol, and sodium nitrite $\left(\mathrm{NaNO}_{2}\right)$ were purchased from Sigma Co. (St. Louis, MO, USA). Ascorbic acid was obtained from Sisco Research Laboratories Pvt. Ltd, Mumbai, India and Methanol obtained from Merck Company, Darmstadt, Germany. HPLC grade solvents were purchased from Rankem (Avanto ${ }^{\mathrm{TM}}$ ), Avantor Performance Materias India Limited, India.

\section{Plant material and preparation of extract}

The leaves of Sarcochlamys pulcherrima (Roxb.) Gaud. was collected from Dhemaji District, Assam in the summer season. The fresh leaves of Sarcochlamys pulcherrima, was washed thoroughly with water and dried under shade and ground into coarse powder. The powdered plant material was finally soaked in the solvent methanol for 4 days with intermittent shaking (Hayet et al., 2008). The extract was filtered through Whatman filter paper No. 1. The process was repeated three times to assure exhaustive extraction. The filtrates were concentrated in a rotatory evaporator (Buchi rotavapor, R-215) at $45^{\circ} \mathrm{C}$ to get the methanol extracts and kept at $4{ }^{\circ} \mathrm{C}$ in refrigerator. From that dried extract, fractionation was carried out using liquid-liquid extraction. The methanol extract (SPM) was suspended in water and extracted successively with hexane, ethyl acetate and butanol to give hexane (SPHF), ethyl acetate (SPEF), n-butanol (SPBF) and residual water (SPWF) fractions respectively. The dried extracts were used for analysis of phenolic content, flavonoids, antioxidant and antimicrobial assays.

\section{Phytochemical screening}

The screening of preliminary phytochemicals in $S$. pulcherrima crude extract and solvent fractions was done to ascertain the presence of bioactive components, namely alkaloids, carbohydrates, phenols, flavonoids, tannin, glycosides and saponins (Raaman, 2006).

\section{Estimation of total phenolic content}

The concentration of phenolics in extracts was determined using Folin-Ciocalteu reagent (Singleton et al., 1999) with slight modification. Briefly $100 \mu \mathrm{L}$ samples $(1 \mathrm{mg} / \mathrm{mL}) /$ blank or standard gallic acid (various concentration 1-100 $\mu \mathrm{g} / \mathrm{mL}$ ) was mixed with $500 \mu \mathrm{L}$ Folin-Ciocalteu reagent $(10 \% \mathrm{v} / \mathrm{v})$ in $2 \mathrm{~mL}$ assay tube and kept for $10 \mathrm{~min}$. Then $400 \mu \mathrm{L}$ of $7 \% \mathrm{Na}_{2} \mathrm{CO}_{3}$ solution was added. The reaction mixture was shaken vigorously and thereafter incubated at $40^{\circ} \mathrm{C}$ for $30 \mathrm{~min}$. Transferred $300 \mu \mathrm{L}$ samples, standard and blank solution from respective assay tubes to clear 96 well microplate and absorbance of each well was determined at $760 \mathrm{~nm}$ in Thermo scientific Multiskan spectrum reader against blank. The concentration of the total phenolics contents was calculated by using an equation obtained from gallic acid calibration curve. The values were expressed as gallic acid equivalents milligram per gram of extract.

\section{Estimation of total flavonoid content}

The content total flavonoids of samples were measure by the method of aluminum chloride $\left(\mathrm{AlCl}_{3}\right)$, colorimetric assay as previously described (Kim et al., 2003). To the 2 $\mathrm{mL}$ test tubes $400 \mu \mathrm{L}$ of water and $100 \mu \mathrm{L}$ of plant extract (1 $\mathrm{mg} / \mathrm{mL}$ ) or standard (various concentration 1-100 $\mu \mathrm{g} / \mathrm{mL})$ were added. To this $30 \mu \mathrm{L}$ of $5 \%$ sodium nitrite and at $5 \mathrm{~min} 30 \mu \mathrm{L}$ of $10 \%$ aluminum chloride were added. After $6 \mathrm{~min}, 200 \mu \mathrm{L}$ of $1 \mathrm{M}$ sodium hydroxide was added and the volume made up to $1 \mathrm{~mL}$ with water $(240$ $\mu \mathrm{L})$. After 15 minutes absorbance was measured at 510 $\mathrm{nm}$. The total flavonoids were calculated from Calibration curve of catechin $(10-250 \mu \mathrm{g} / \mathrm{mL})$ plotted by using the same procedure and total flavonoids was expressed as catechin equivalents milligram per gram sample.

\section{Antioxidant activity DPPH radical scavenging assay}

Radical scavenging activity of plant extracts were determined by colorimetric assay using 2, 2-diphenyl picryl hydrazyl radical (DPPH) as source of free radical as stated by the method of (Blois, 1958) with a slight modification. Briefly, a $0.1 \mathrm{mM}$ solution of DPPH radical solution in methanol was prepared. In a clear 96 well plate $100 \mu \mathrm{L}$ of standard Ascorbic acid or sample in various concentration $(1-100 \mu \mathrm{g} / \mathrm{mL})$ and $100 \mu \mathrm{L}$ methanol/water was transferred and then $200 \mu \mathrm{L}$ of DPPH solution was added. The reaction mixture was left for $30 \mathrm{~min}$ at room temperature in dark. The absorbance of each 96 well was measured at $517 \mathrm{~nm}$ in Thermo Multiskan reader. This activity is given as percent DPPH scavenging and is calculated as:

$\%$ DPPH scavenging $=\left(\frac{\text { Conrol absorbance }- \text { Extracts absorbance }}{\text { Control absorbance }}\right) \times 100$

\section{Reducing power assay}

Total reducing power was determined as described by Oyaizu (1986). Briefly, $1 \mathrm{~mL}$ test extracts $(1-100 \mu \mathrm{g} / \mathrm{mL})$ were mixed with $2.5 \mathrm{~mL}$ of Sodium phosphate buffer $(0.2$ $\mathrm{M}, \mathrm{pH}$ 6.6) and $2.5 \mathrm{~mL}$ of potassium ferricyanide (1\%) and then the mixture was incubated at $50^{\circ} \mathrm{C}$ for $20 \mathrm{~min}$. After adding $2.5 \mathrm{~mL}$ of trichloro acetic acid $(10 \%)$ in to the reaction mixture it was centrifuged at $3000 \mathrm{rpm}$ for 10 min. Finally, $2.5 \mathrm{~mL}$ of the supernatant was mixed with $2.5 \mathrm{~mL}$ of distilled water followed by addition of $0.5 \mathrm{~mL}$ $\mathrm{FeCl}_{3}(0.1 \%)$. The absorbance was measured at $700 \mathrm{~nm}$. Increased in absorbance of the reaction mixture indicated increased reducing power, and the $\mathrm{EC}_{50}$ value is the effective concentration at which the absorbance was 0.5 for reducing power.

\section{HPLC analysis}

The HPLC analysis was performed with A Shimadzu LC20AD HPLC system (Shimadzu, Japan) with a binary solvent delivery system (LC-20AD), a Rheodyne injector with $20 \mu \mathrm{L}$ sample loop and DAD detector (SPD-M $20 \mathrm{~A}$ ). Chromatographic separation was performed using a reverse phase column (Capcelll Pack C-18, MGII, 5um, $250 \mathrm{~mm} \times 4.6 \mathrm{~mm}$ ) with an extended guard column. The mobile phase consisted of methanol-acetonitrile-water $(40: 15: 45, \mathrm{v} / \mathrm{v} / \mathrm{v})$ containing $1.0 \%$ acetic acid with isocratic elution for 30 minutes. Shimadzu LC solution software was used for the data acquisition and processing. The diode array detector was set at an acquisition range from $240-800 \mathrm{~nm}$. The flow rate was $1 \mathrm{~mL} / \mathrm{min}$ and injection volume for all samples and standard solutions was $20 \mu \mathrm{L}$. The analytes peaks were identified by matching their retention times and UV spectra with those of the reference standards and the peaks were confirmed by spiking the sample with a small amount of the standards. 


\section{Determination of antimicrobial activities}

The antimicrobial properties of S. pulcherrima (Roxb.) Gaud were investigated against one gram negative bacterial strain; Escherichia coli ATCC-11229, three gram positive bacterial strains; Bacillus cereus MTCC-430, Staphylococcus aureus ATCC-11632, Enterococcus faccium ATCC-35667, one fungal species; Aspergilus niger ATCC16888 and one yeast species; Candida albicans ATCC-10231. All strains were sub-cultured before use. Bacteria were cultured on Luria Bertani (LB) Agar at $37^{\circ} \mathrm{C}$ for $24 \mathrm{~h}$, while fungi were cultured on potato dextrose agar medium at $30^{\circ} \mathrm{C}$ for $48 \mathrm{~h}$. Then these activated bacteria and fungi were aseptically transferred to a Luria Bertani broth medium, and cultured in an incubator at $37^{\circ} \mathrm{C}$ for $24 \mathrm{~h}$. The density of each microorganism was further adjusted to a turbidity equivalent to 0.5 on the McFarland scale before use.

\section{Measurement of inhibition zone diameter}

The agar diffusion method (Parekh and Chanda, 2006; Perez et al., 1990) with some modification was used to evaluate the antimicrobial activity. The crude extract and fractions were allowed to diffuse out into the agar medium and interact in a plate with freshly seeded test organisms. The sterile liquid nutrient agar was autoclaved and then poured $20-25 \mathrm{~mL}$ of heated LB agar into each petriplate. After the liquid agar was cooled down and solidified, $100 \mu \mathrm{L}$ of bacteria/ fungi suspension were uniformly spread onto the surface with the help of sterile L-spray rolled to make a microbial lawn. The plates were punched to make well of $5 \mathrm{~mm}$ diameter using a sterile metallic cylinder and $20 \mu \mathrm{L}(4 \mathrm{mg} /$ well $)$ of plant extracts dissolved in dimethyl sulfoxide (DMSO; $200 \mathrm{mg} / \mathrm{mL}$ ) and $10 \mu \mathrm{L}$ of standards $(10 \mu \mathrm{g} /$ well $)$ were added into each well. Then the bacteria were incubated at $37^{\circ} \mathrm{C}$ for $24 \mathrm{~h}$, and fungi were incubated at $30^{\circ} \mathrm{C}$ for $48 \mathrm{~h}$. Gentamycin for bacteria and Nystatin for fungi was used as positive controls. Dimethyl sulfoxide was used as a negative control. Antimicrobial activities were evaluated by measuring the diameters of inhibition zone. Each sample was repeated in triplicate.

\section{Determination of minimum inhibitory concentration}

The minimum inhibition concentration (MIC) is the lowest concentration of antimicrobial agent at which no growth of microorganism was observed. MIC was determined by broth microdilution method using 96-well plates (Karaman et al., 2003). All the extracts were dissolved in $10 \%$ Dimethyl sulfoxide in order to make stock solution of $25 \mathrm{mg} / \mathrm{mL}$. In a 96-well plates $100 \mu \mathrm{L}$ of nutrient broth were dispensed into each well. A $100 \mu \mathrm{L}$ of S. pulcherrima extracts (prepared with initial concentration $25 \mathrm{mg} / \mathrm{mL}$ ) was added into the first wells of each column. Then, a serial two-fold dilution was performed into seven consecutive wells of each column. Lastly, $100 \mu \mathrm{L}$ of microbial inoculum $\left(10^{6} \mathrm{CFU}\right)$ diluted in $0.9 \%$ saline water was pipetted into each wells. $100 \mu \mathrm{L}$ of nutrient broth with or without $100 \mu \mathrm{L}$ of inoculum served as control. The plates were then covered with sterile covers and sealed with a sterile parafilm and incubated at optimum conditions for each pathogen. As reference antibiotic, gentamycin was employed. After incubation, $40 \mu \mathrm{L}$ of a $0.4 \mathrm{mg} / \mathrm{mL}$ nitroblue trotetrazolium chloride (NBT) indicator was added to visualize growth inhibition in each well, followed by $20 \mathrm{~min}$ incubation at $37^{\circ} \mathrm{C}$. Bacterial growth in the wells was indicated by a blue colour, whereas clear wells indicated inhibition of growth by the tested sample. The minimum inhibitory concentration
Table 1: Qualitative phytochemical screening of methanol crude extract and its derived fractions from S. pulcherrima.

\begin{tabular}{|c|c|c|c|c|c|c|}
\hline \multirow{2}{*}{\multicolumn{2}{|c|}{ Phytochemical test }} & \multicolumn{5}{|c|}{$\begin{array}{l}\text { Extracts of Sarchoclamys pulcher- } \\
\text { rima }\end{array}$} \\
\hline & & \multirow[t]{2}{*}{$\overline{\text { SPM }}$} & \multirow[t]{2}{*}{ SPHF } & \multicolumn{2}{|c|}{ SPEAF SPBF } & \multirow[t]{2}{*}{ SPWF } \\
\hline Alkaloids & & & & & & \\
\hline a) & Mayer's reagent & + & - & + & + & + \\
\hline b) & Wagner's reagent & - & - & - & - & - \\
\hline c) & Hager's reagent & + & + & + & - & + \\
\hline \multicolumn{7}{|c|}{ Carbohydrates \& glycosides } \\
\hline a) & Molish's test & + & + & + & + & + \\
\hline b) & Fehling's test & + & + & - & + & + \\
\hline c) & Barfoed's test & + & - & - & + & + \\
\hline d) & Benedict's test & + & + & + & - & - \\
\hline e) & Borntrager's test & - & + & + & + & - \\
\hline f) & Legal's test & + & + & + & - & + \\
\hline \multicolumn{7}{|l|}{ Saponins } \\
\hline Foam test & & + & + & + & + & + \\
\hline \multicolumn{7}{|c|}{$\begin{array}{l}\text { Phenolic compound and } \\
\text { flavonoids }\end{array}$} \\
\hline a) & Ferric chloride test & + & + & + & + & + \\
\hline b) & Lead acetate test & + & + & + & + & + \\
\hline c) & Alkaline reagent & + & + & - & + & + \\
\hline d) & $\begin{array}{l}\text { Magnesium and } \mathrm{HCl} \\
\text { acid reduction }\end{array}$ & - & - & + & + & - \\
\hline \multicolumn{7}{|c|}{ Proteins and amino acids } \\
\hline a) & Milon's reagent & + & + & + & - & + \\
\hline b) & Ninhydrin reagent & + & + & + & + & + \\
\hline \multicolumn{7}{|c|}{ Phytosteroids } \\
\hline Liebrmanr & n-burchard's test & + & - & + & + & - \\
\hline
\end{tabular}

was defined as the lowest concentration of the test sample where there is no visible microbial growth (as indicated by colour). The MIC value was recorded as the mean concentration of triplicates.

\section{Statistical analysis}

The results obtained were stated in mean \pm SD for three replicates. Statistical analysis was performed and graphs were obtained using Microsoft Excel (Microsoft office 2010).

\section{RESULTS AND DISCUSSION}

\section{Phytochemical screening}

The phytochemicals screening conducted on the methanol crude extract and it derived fractions of S. pulcherrima, exhibited the presence of alkaloids, carbohydrates, flavonoids, phenolic compounds, saponins, and phytosteroids (table 1). Phytosteroids is not found in SPHF and SPWF; it is possible that the presence of phytoconstituents might be responsible for the bioactivity of the plant extracts (Ndukwe et al., 2005).

\section{Total phenolics and flavonoids content}

The total phenolics and total flavonoids content of methanol extract and its derived solvent fractions from $S$. pulcherrima are shown in table 2 . The content of phenolics was calculated from the regression equation of the calibration curve $\left(\mathrm{R}^{2}=0.9923, \mathrm{y}=0.008 x+0.0511\right)$, expressed in GAE as milligrams per gram of the extract or fraction (GAE mg /g extract or fraction) and flavonoids content was calculated from the regression equation of calibration curve $\left(\mathrm{R}^{2}=0.9936, \mathrm{y}=0.0022 \mathrm{x}+0.0293\right)$, expressed in Catechin equivalent as milligrams per gram of extract or fraction (CTE $\mathrm{mg} / \mathrm{g}$ extract or fraction). The total phenolics and flavonoids content of methanol extract are $136.932 \pm 0.29 \mathrm{GAE} \mathrm{mg/g}$. and $54.663 \pm 4.32 \mathrm{CTE} \mathrm{mg} / \mathrm{g}$, respectively. Among the four fraction extracts, ethyl 
Table 2: Total phenolics content, total flavonoids content and antioxidant activity of the extract of Sarcochlamys pulcherrima.

\begin{tabular}{|c|c|c|c|c|}
\hline Sample & TPC (mg/g GAE) & TFC (mg/g CTE) & DPPH EC $50^{\mathrm{a}}(\mu \mathrm{g} / \mathrm{mL})$ & Reducing power $\mathrm{EC}_{50^{\mathrm{b}}}(\mu \mathrm{g} / \mathrm{mL})$ \\
\hline$\overline{\mathrm{SPM}}$ & $136.93 \pm 0.29$ & $54.66 \pm 4.32$ & $36.05 \pm .191$ & $309.89 \pm 4.32$ \\
\hline SPHF & $36.94 \pm 6.22$ & $34.98 \pm 3.51$ & $214.66 \pm 14.09$ & $1176.79 \pm 19.80$ \\
\hline SPEAF & $201.37 \pm 1.31$ & $109.48 \pm 3.58$ & $32.09 \pm 0.19$ & $180.75 \pm 9.87$ \\
\hline SPBF & $197.76 \pm 2.43$ & $91.99 \pm 3.04$ & $14.69 \pm 0.26$ & $162.65 \pm 8.52$ \\
\hline SPWF & $55.05 \pm 0.19$ & $8.63 \pm 3.51$ & $76.23 \pm 2.52$ & $918.51 \pm 18.89$ \\
\hline AA & & & $8.91 \pm 0.017$ & $100.27 \pm 1.14$ \\
\hline
\end{tabular}

Each value is expressed as mean \pm standard deviation $(n=3)$.

${ }^{\mathrm{a} E C_{50}}(\mu \mathrm{g} / \mathrm{mL})$ : effective concentration at which $50 \%$ of DPPH radicals are scavenged.

${ }^{\mathrm{b}} \mathrm{EC}_{50}(\mu \mathrm{g} / \mathrm{mL})$ : effective concentration at which the absorbance is 0.5 .

TPC: total phenolics content, TFC: total flavonoids content, AA: Ascorbic acid

Table 3: Mean content of rutin, gallic acid, quercetin and kaempferol (mg/g \pm SD) quantified by HPLC in extracts of S. pulcherrima.

\begin{tabular}{|c|c|c|c|c|c|}
\hline & SPM & SPHF & SPEAF & SPBF & SPWF \\
\hline Rutin & $28.93 \pm 2.89$ & $4.64 \pm .13$ & $77.53 \pm 7.57$ & $77.45 \pm 1.71$ & ND \\
\hline Quercetin & $0.924 \pm 0.43$ & $0.898 \pm 0.18$ & $1.287 \pm 0.45$ & ND & ND \\
\hline Gallic acid & $18.34 \pm 0.54$ & $2.79 \pm 0.02$ & $61.01 \pm 2.34$ & $22.75 \pm 1.54$ & $7.08 \pm 0.37$ \\
\hline Kaempferol & $0.435 \pm 0.29$ & $0.355 \pm 0.04$ & $0.425 \pm 0.64$ & $1.212 \pm 0.49$ & ND \\
\hline
\end{tabular}

Values were determined from integration of HPLC signals and response factors calculated from standards, Each value is expressed as mean \pm standard

deviation $(\mathrm{n}=3) .{ }^{\mathrm{a}}=$ Dry weight of the extract of S. pulcherrima. $\mathrm{ND}=$ Not detected.

Table 4: Antimicrobial activity measured as zone of inhibition at $30 \mu \mathrm{L}(200 \mathrm{mg} / \mathrm{mL})$ of crude methanol extract, its derived fractions from S. pulchrrima and standard atibiotics.

\begin{tabular}{|c|c|c|c|c|c|c|c|}
\hline \multirow{2}{*}{ Microbial species } & \multicolumn{7}{|c|}{ Zone of inhibition (mm) } \\
\hline & SPM & SPHF & SPEAF & SPBF & SPWF & Gentamycin & Nystatin \\
\hline B.cereus & $10 \pm 0.00$ & - & $10 \pm 0.00$ & $11 \pm 0.00$ & $7 \pm 0.00$ & $22 \pm 0.00$ & * \\
\hline S. aureus & $9 \pm 0.00$ & - & $8 \pm 0.00$ & $11 \pm 0.00$ & $6 \pm 0.00$ & $20 \pm 0.00$ & * \\
\hline E. faccium & - & - & - & - & - & $12 \pm 0.00$ & * \\
\hline E. coli & $8 \pm 0.00$ & - & $8 \pm 0.00$ & $7 \pm 0.00$ & $6 \pm 0.00$ & $19 \pm 0.00$ & * \\
\hline A. niger & - & - & - & - & - & * & $11 \pm 0.00$ \\
\hline C. Albicans & - & - & - & - & - & * & $12 \pm 0.00$ \\
\hline
\end{tabular}

Table 5: The MIC values of S. pulcherrima extract against the microorganisms tested in microdilution assay

\begin{tabular}{llllll}
\hline Microbial species & MIC & SPEAF & SPBF & SPWF & Gentamycin \\
\cline { 2 - 6 } & SPM & 1.56 & 1.56 & 6.25 & 3.13 \\
B. cereus & 3.13 & 1.56 & 1.56 & 12.5 & 6.25 \\
S. aureus & 1.56 & 1.56 & 0.781 & 6.25 & 6.25 \\
E. coli & 3.125 & &
\end{tabular}

MIC: minimal inhibition concentration ( $\mathrm{mg} / \mathrm{mL}$ for sample and $\mu \mathrm{g} / \mathrm{mL}$ for Standard).

Each value is expressed as mean \pm standard deviation $(n=3)$.

acetate fraction was contain highest $(201.370 \pm 1.31$ GAE $\mathrm{mg} / \mathrm{g}$ ) amount of phenolic compounds followed by $\mathrm{n}$ butanol fraction $(197.763 \pm 2.43 \mathrm{GAE} \mathrm{mg} / \mathrm{g})$, water fraction $(55.051 \pm 0.19 \mathrm{GAE} \mathrm{mg} / \mathrm{g})$ and hexane fraction $(36.945 \pm$ 6.22 GAE $\mathrm{mg} / \mathrm{g}$ ). The flavonoids content of fraction extracts were in descending order of SPEAF $(109.484 \pm$ $3.58 \mathrm{CTE} \mathrm{mg} / \mathrm{g})>\mathrm{SPBF}(91.994 \pm 3.04 \mathrm{CTE} \mathrm{mg} / \mathrm{g})>\mathrm{SPHF}$ $(34.983 \pm 3.51 \mathrm{CTE} \mathrm{mg} / \mathrm{g})>$ SPWF $(8.631 \pm 3.51 \mathrm{CTE} \mathrm{mg} / \mathrm{g})$.

\section{Antioxidant activity}

The results of the antioxidant activity determined by two test assays, viz. - DPPH radical scavenging and reducing power activity are shown in table 2 . In the present study, the capacity of the extract samples to scavenge DPPH radical was determined on the basis of their concentration providing $50 \%$ inhibition (EC50). N-butanol fraction of the plant extract showed the highest radical scavenging activity with an $\mathrm{EC}_{50}$ value of $14.69 \pm 0.26 \mu \mathrm{g} / \mathrm{mL}$ followed by ethyl acetate fraction $\left(\mathrm{EC}_{50}=32.09 \pm 0.19 \mu \mathrm{g} / \mathrm{mL}\right)$ and methanol crude extract $\left(\mathrm{EC}_{50}=36.05 \pm 0.191 \mu \mathrm{g} / \mathrm{mL}\right)$. The water fractions showed moderate while hexane fraction showed lowest antioxidant activity in this assay. Figure 1(A) showed the radical scavenging ability of S. pulcherrima crude extract and fractions on DPPH in different concentrations. At concentration from 1 to $100 \mu \mathrm{g} / \mathrm{mL}$, DPPH-radical scavenging ability (RSA) of SPM range $3.43-92.89 \%$, SPEAF range $1.54-93.21 \%$ and SPBF range $5.05-92.41 \%$ showed strong activity, while SPWF range $2.78-64.33 \%$ and SPHF rang $2.24-23.45 \%$ showed week antioxidant activity. On the other hand DPPH-RSA of ascorbic acid range 7.93-95.74\% and $\mathrm{EC}_{50} 8.91 \pm 0.017$ $\mu \mathrm{g} / \mathrm{mL}$. The radical scavenging activity of the leaf extract and different solvent fractions of S. pulcherrima may be due to its phenolic compounds.

The reducing power assay is simple and direct method to assay antioxidant power. The antioxidants can transform $\mathrm{Fe}_{3}+(\mathrm{CN}-)_{6}$ into $\mathrm{Fe}_{2}+(\mathrm{CN}-)_{6}$, so that the reducing power can be monitored by measuring Prussian blue formation at $700 \mathrm{~nm}$. Increased absorbance is correlated with the reducing power of the extracts. A dose-response relationship was found in reducing ability of plant extract (figure 1B); the reducing capacity is 

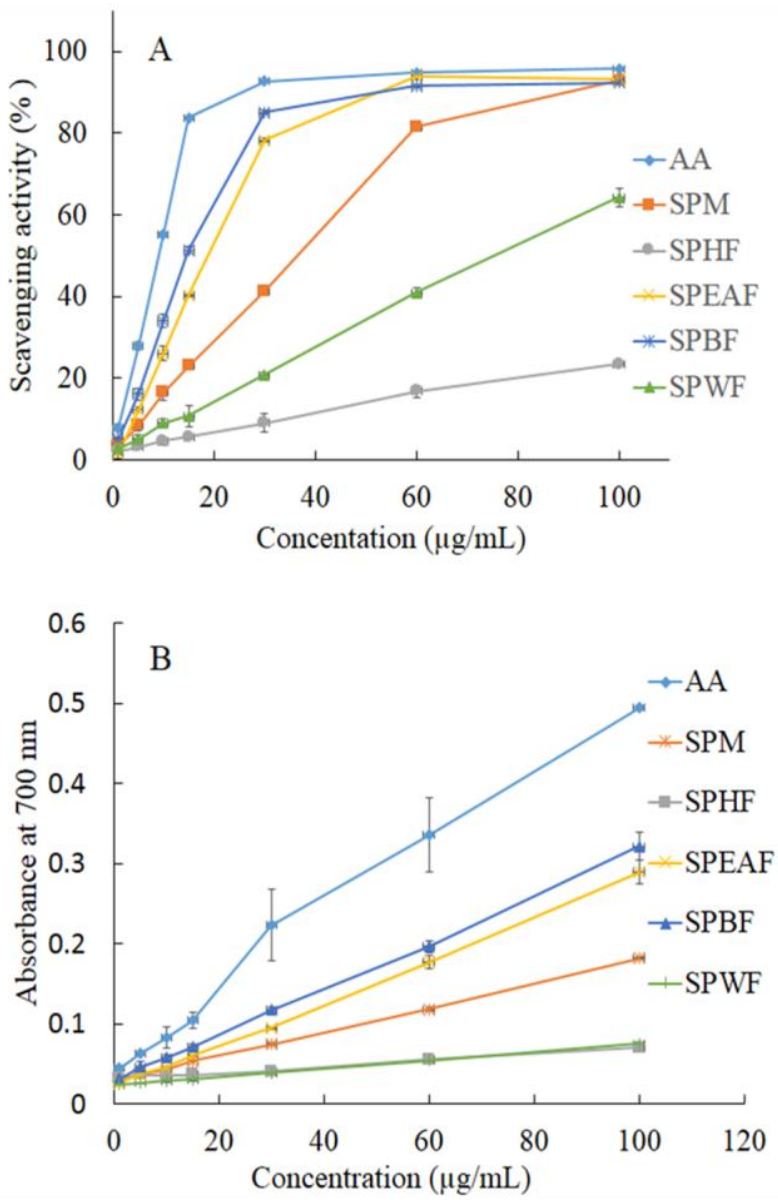

Figure 1: Antioxidant properties of crude methanol extract and its solvent fraction from Sarcochlamys pulcherrima. Each value is expressed as mean \pm standard deviation $(n=3)$. (A) DPPH radical scavenging activity; (B) Reducing power.
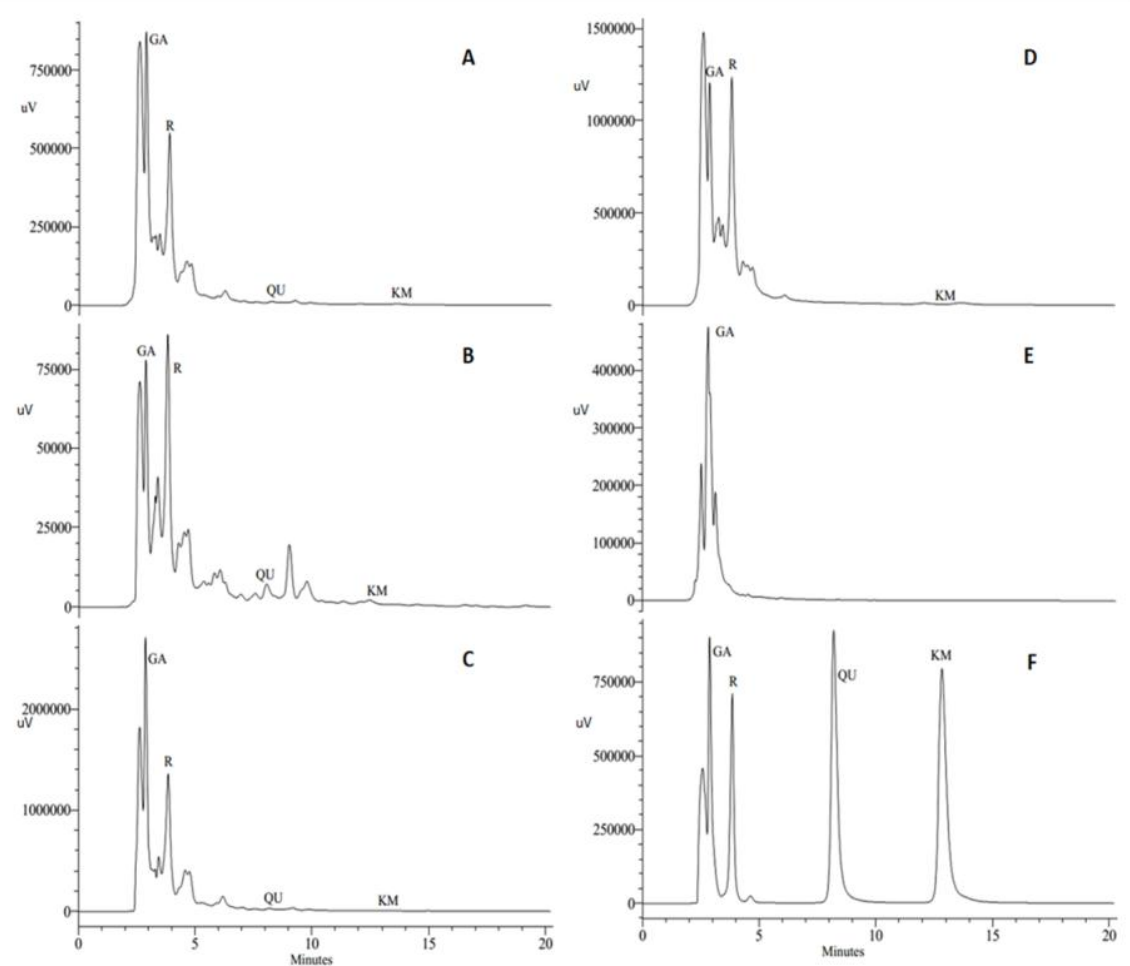

increasing with increased in concentration of extract. The reducing ability, $\mathrm{EC}_{50}$ (effective concentration at which the absorbance is 0.5) values of SPM, SPHF, SPEAF, SPBF and SPWF were $309.890 \pm 4.32 \mu \mathrm{g} / \mathrm{mL}, 1176.789 \pm 19.80 \mu \mathrm{g} / \mathrm{mL}$, $180.752 \pm 9.87 \mu \mathrm{g} / \mathrm{mL}, 162.646 \pm 8.52 \mu \mathrm{g} / \mathrm{mL}$, and 918.506 $\pm 18.89 \mu \mathrm{g} / \mathrm{mL}$ respectively. Ascorbic acid as the positive control $\left(\mathrm{EC}_{50}=100.268 \pm 1.14 \mu \mathrm{g} / \mathrm{mL}\right)$. The reducing properties are generally related with the existence of reductones (Duh, 1998).

\section{HPLC analysis}

In order to determine the various components with antioxidant and antimicrobial activities, an HPLC method was developed to quantify rutin, gallic acid, quercetin and kaempferol in methanol crude extract and its different solvent fractions of S. pulcherrima. The HPLC chromatograms of extracts and tested compound are shown in figure 2. Quantification was done via a calibration with standards (external standard method). The amount of compound detected in the analyzed samples is shown in table 3. Results are expressed in $\mathrm{mg} / \mathrm{g}$ dry extract. The content of rutin $(28.93 \pm 2.89 \mathrm{mg} / \mathrm{g})$ represent the highest amount of phenolic substance, followed by gallic acid $(18.34 \pm 0.54 \mathrm{mg} / \mathrm{g})$, qurcetin $(0.924 \pm 0.43 \mathrm{mg} / \mathrm{g})$, and kaempferol $(0.435 \pm 0.29 \mathrm{mg} / \mathrm{g})$ in the methanol crude extract. Among the solvent fractions the content of rutin in SPEAF shows the highest amount $(77.53 \pm 7.57 \mathrm{mg} / \mathrm{g})$ followed by SPBF $(77.45 \pm 1.71 \mathrm{mg} / \mathrm{g})$, SPHF $(4.64 \pm .13$ $\mathrm{mg} / \mathrm{g})$ and gallic acid $(61.01 \pm 2.34 \mathrm{mg} / \mathrm{g})$. On the other hand in SPWF only gallic acid is able to determine, the other phenolic substaince may be absent or present in untraceable amount.

\section{Antimicrobial activity}

The antimicrobial activities of S. pulcherrima methanol crude extract and fraction extracts against three gram positive bacteria, one gram negative bacteria and two strains of fungi were investigated and their effectiveness were quantitatively determined through the presence or absence of inhibition zones and zone diameter (table 4) and MIC values (table 5). The results indicated that the
Figure 2: HPLC chromatogram of standard mixture and plant extracts. (A) methanol crude extract; (B) hexane fraction; (C) ethyl acetate fraction; (D) nbutanol fraction; (E) water fraction; (F) standard mixture. $\mathrm{GA}$, gallic acid; $\mathrm{R}$, rutin; $\mathrm{QU}$, quercetin; KM, kaempferol. 
methanol crude extract, ethyl acetate fraction, n-butanol fraction and water fraction from S. pulcherrima has inhibition effect on growth of three bacterial species which were Bacillus cereus, Staphylococcus aureus and Escherichia coli but had no antimicrobial activity against E. faccium bacterial strain and one yeast \& fungal strains namely Candida albicans and Aspergillus nizer. However, the hexane fraction showed no antimicrobial activity against any of the bacterial and fungal strains in the present study. The ethyl acetate and n-butanol fraction showed the best antimicrobial activity with most noteworthy activity observed for n-butanol fraction $(0.781 \mathrm{mg} / \mathrm{mL})$ against E. coli. Water fraction exhibited the least antimicrobial activity with MIC value range $6.25-12.5 \mathrm{mg} / \mathrm{mL}$, against all the strains. The highest inhibitory zone (11 $\mathrm{mm}$ ) was observed in $\mathrm{n}$-butanol fraction against B. cereus and $S$. aureus. This result shows that high polar fractions in the plant are having good antimicrobial activities.

\section{CONCLUSION}

In the present investigation, comparing to all the extract n-butanol fraction from S. pulcherrima exhibited strongest radical scavengers in DPPH $(14.69 \mu \mathrm{g} / \mathrm{mL})$ and highest reducing power $(162.65 \mu \mathrm{g} / \mathrm{mL})$. While the ethyl acetate fraction showed highest amount of total phenol and total flavonoid content among the solvent fraction but possessed lower antioxidant activity than SPBF in the present study. Although in other three fraction total phenols and flavonoids content are directly correlate with the antioxidant activity and in SPBF total phenols and flavonoids content is slightly lower than the SPEAF but shows highest antioxidant activity. Therefore, the total phenols and total flavonoids are not only responsible for the antioxidant activity, other primary and secondary metabolites also may be responsible for antioxidant activity. Estimation of rutin, gallic acid, quercetin and kaempferol in methanol crude extract and its derived fractions are determined by reverse phase HPL analysis, which had not been reported previously. The antimicrobial results of this study support several traditional medicinal uses of $S$. pulcherrima species in Assam. Methanol crude extracts and its derived fraction from $S$. pulcherrima show antimicrobial effects on the tested microorganisms as well as possessed high antioxidant activity. These results justified the traditional use of $S$. pulcherrima in the treatment of diarrhea, dysentery and cancer. However, further research on the isolation and characterizations of active compound from SPEAF and SPBF is still needed.

\section{REFERENCES}

Bayr, H. (2005). Reactive oxygen species. Critical care medicine, 33(12), S498S501. [DOI]

Blois, M. S. (1958). Antioxidant determinations by the use of a stable free radical. [DOI]

Das, D., Bandyopadhyay, D., Bhattacharjee, M., \& Banerjee, R. K. (1997). Hydroxyl radical is the major causative factor in stress-induced gastric ulceration. Free Radical Biology and Medicine, 23(1), 8-18. [DOI]

Droge, W. (2002). Free radicals in the physiological control of cell function.Physiological reviews, 82(1), 47-95. [DOI]

Duh, P. D. (1998). Antioxidant activity of burdock (Arctium lappa Linne) its scavenging effect on free-radical and active oxygen. Journal of the American Oil Chemists' Society, 75(4), 455-461. [DOI]

Hayet, E., Maha, M., Samia, A., Mata, M., Gros, P., Raida, H. \& Mahjoub, A. (2008). Antimicrobial, antioxidant, and antiviral activities of Retama raetam (Forssk.) Webb flowers growing in Tunisia. World Journal of Microbiology and Biotechnology, 24(12), 2933-2940. [DOI]

Kähkönen, M. P., Hopia, A. I., Vuorela, H. J., Rauha, J. P., Pihlaja, K Kujala, T. S., \& Heinonen, M. (1999). Antioxidant activity of plant extracts containing phenolic compounds. Journal of agricultural and food chemistry, 47(10), 3954-3962. [DOI]

Karaman, I., Şahin, F., Güllüce, M., Öğütçü, H., Şengül, M., \& Adıgüzel, A. (2003). Antimicrobial activity of aqueous and methanol extracts of Juniperus oxycedrus L. Journal of ethnopharmacology, 85(2), 231-235. [DOI

Kim, D. O., Jeong, S. W., \& Lee, C. Y. (2003). Antioxidant capacity of phenolic phytochemicals from various cultivars of plums. Food chemistry, 81(3), 321-326. [DOI]

Maqsood, S., Singh, P., Samoon, M. H., \& Balange, A. K. (2010). Effect of dietary chitosan on non-specific immune response and growth of Cyprinus carpio challenged with Aeromonas hydrophila. International Aquatic Research, 2(2), 77-85. [Link]

Muramatsu, H., Kogawa, K., Tanaka, M., Okumura, K., Nishihori, Y., Koike, K., Kuga, T., \& Niitsu, Y. (1995). Superoxide dismutase in SAS human tongue carcinoma cell line is a factor defining invasiveness and cell motility. Cancer Research, 55(24), 6210-6214. PMID: 8521415

Ndukwe, K. C., Okeke, I. N., Lamikanra, A., Adesina, S. K., \& Aboderin, O (2005). Antibacterial activity of aqueous extracts of selected chewing sticks. J. Contemp. Dent. Pract, 6(3), 086-094. [Link]

Oyaizu, M. (1986). Studies on product of browning reaction prepared from glucose amine. Japanese Journal of Nutrition, 44(6): 307-315. [DOI]

Parekh, J., \& Chanda, S. (2006). Screening of aqueous and alcoholic extracts of some Indian medicinal plants for antibacterial activity. Indian journal of pharmaceutical sciences, 68(6), 835. [DOI]

Pisoschi, A. M., Cheregi, M. C., \& Danet, A. F. (2009). Total antioxidant capacity of some commercial fruit juices: electrochemical and spectrophotometrical approaches. Molecules, 14(1), 480-493. [DOI]

Perez, C, Paul, M, \& Bazerque, P. (1990). An antibiotic assay by the agar well diffusion method. Acta Biol Med Exp, 15, 113-115.

Proestos, C., Boziaris, I. S., Nychas, G. J., \& Komaitis, M. (2006). Analysis of flavonoids and phenolic acids in Greek aromatic plants: Investigation of their antioxidant capacity and antimicrobial activity. Food Chemistry, 95(4), 664-671. [DOI]

Raaman, N. (2006). Phytochemical techniques. New India Publishing.

Sharma, U. K., \& Pegu, S. (2011). Ethnobotany of religious and supernatural beliefs of the Mising tribes of Assam with special reference to the'Dobur Uie'.Journal of ethnobiology and ethnomedicine, 7(1), 1. [DOI]

Singleton, V.L., Orthofer R., Lamuela-Raventos R.M. (1999). Analysis of total phenols and other oxidation substrates and antioxidants by means of folin-ciocalteu reagent. Methods in Enzymology, 299, 152-178. [DOI]

Sorbara, M. T., \& Girardin, S. E. (2011). Mitochondrial ROS fuel the inflammasome. Cell research, 21(4), 558. [DOI]

Wu, Z. Y., Monro, A. K., Milne, R. I., Wang, H., Yi, T. S., Liu, J., \& Li, D. Z. (2013). Molecular phylogeny of the nettle family (Urticaceae) inferred from multiple loci of three genomes and extensive generic sampling. Molecular phylogenetics and evolution, 69(3), 814-827. [DOI] 